\title{
PENGEMBANGAN MEDIA PEMBELAJARAN TENSES BAHASA INGGRIS BERBASIS MULTIMEDIA INTERAKTIF PADA SISWA SEKOLAH DASAR
}

\author{
Nana Ronawan Rambe ${ }^{1}$, Abdul Hasan Saragih ${ }^{2}$ \\ Teknologi Pendidikan Pascasarjana Universitas Negeri Medan \\ Nana_ronawa@yahoo.com ${ }^{1}$
}

\begin{abstract}
Abstrak: Penelitian dan pengembangan ini bertujuan untuk: (1) Menghasilkan media pembelajaran interaktif yang layak digunakan, mudah dipelajari dan dapat dipakai untuk pembelajaran individual, (2) Untuk mengetahui keefektifan media pembelajaran interaktif yang dikembangkan pada mata pelajaran Bahasa Inggris. Metode penelitian adalah Research and Development dengan menggunakan model Dick and Carey. Hasil pengujian hipotesis membuktikan bahwa terdapat perbedaan yang signifikan antara hasil belajar siswa yang dibelajarkan dengan menggunakan multimedia interaktif dengan hasil belajar siswa yang dibelajarkan dengan tanpa menggunakan multimedia interaktif. Hal ini ditunjukkan dengan hasil pengolahan data dimana diperoleh t hitung sebesar 9.0229, sedangkan t tabel $=1.98$, pada $\alpha=0.05$ dengan $\mathrm{dk} 98$. Hasil perhitungan dimana thitung > t tabel, t hitung yaitu 9.0229>1.98. Disimpulkan bahwa hasil belajar kelompok siswa yang dibelajarkan dengan menggunakan pembelajaran multimedia interaktif adalah sebesar $95.63 \%$ dan lebih tinggi dari kelompok siswa yang dibelajarkan dengan tanpa menggunakan pembelajaran multimedia interaktif, yaitu sebesar $90.00 \%$.
\end{abstract}

Kata Kunci: media pembelajaran tenses bahasa inggris berbasis multimedia interaktif

Abstract: The research and development is aimed at: (1) Produce interactive learning media that is fit for use, easy to learn and can be used for individual learning, (2) To determine the effectiveness of interactive learning media developed in subjects in English. The research method is the Research and Development using a model of Dick and Carey. Hypothesis testing results prove that there is a significant difference between the learning outcomes of students that learned using interactive multimedia learning outcomes of students that learned without using interactive multimedia. This is indicated by the data processing which gained $t$ count equal to 9.0229 , while the tables $t=1.98$, at $\alpha$ $=0: 05$ to $98 \mathrm{hp}$. The results of calculations where thitung $>\mathrm{t}$ table, ie $9.0229 \mathrm{t}>1.98$. It was concluded that the results of the study group of students that learned using interactive multimedia learning amounted to $95.63 \%$ and higher than the group of students that learned without using interactive multimedia learning, which amounted to $90.00 \%$.

Keywords: media learning English tenses based interactive multimedia

\section{PENDAHULUAN}

Bahasa Inggris merupakan alat untuk berkomunikasi secara lisan dan tulisan. Berkomunikasi adalah memahami dan mengungkapkan informasi, fikiran, perasaan, dan mengembangkan ilmu pengetahuan, teknologi, dan budaya. Bahasa Inggris adalah bahasa global yang sangat berperan dalam interaksi dan komunikasi global seiring dengan kemajuan dan persaingan globalisasi seperti sekarang ini. Agar informasi yang ada dengan cepat dapat diterima, maka bahasa sebagai pengantar pesan harus benar-benar dipahami dan dimengerti baik secara lisan maupun tulisan. Bahasa Inggris merupakan salah satu pelajaran bahasa asing yang diajarkan di sekolah.
Mangingat pentingnya peran Bahasa Inggris di abad 21, pemerintah telah menetapkan Bahasa Inggris sebagai bahasa asing yang wajib dipelajari di sekolah untuk tingkatan SMP dan SMA. Berbeda dengan tingkat Sekolah Dasar, Mata pelajaran Bahasa Inggris secara resmi diajarkan disekolah dasar sejak tahun 1994 sebagai muatan lokal.

Kebijakan tentang pemberian pelajaran bahasa Inggris di sekolah dasar dilandasi dengan kebijakan-kebijakan terkait, diawali dengan kebijakan Departemen Pendidikan Nasional (Depdiknas) No. 0487/4/1992, Bab VIII, menyatakan bahwa sekolah dasar dapat menambah mata pelajaran dalam kurikulumnya, asalkan pelajaran itu tidak bertentangan dengan 
tujuan pendidikan nasional. Mata pelajaran tambahan (muatan lokal) biasanya merupakan mata pelajaran yang memang dibutuhkan oleh sekolah dan masyarakat sekitarnya. Oleh karena itu, mata pelajaran tambahan (muatan lokal) sangat bervariasi antara satu daerah dengan daerah lainnya. Kemudian, kebijakan ini disusul oleh SK Menteri Pendidikan dan Kebudayaan No. 060/U/1993 tanggal 25 Februari 1993 tentang dimungkinkannya program bahasa Inggris diberikan sebagai mata pelajaran muatan lokal SD, dan dapat dimulai pada kelas empat (4) SD. Kurikulum mata pelajaran muatan lokal ini tidak disusun oleh Pusat Kurikulum Depdiknas tetapi dikembangkan di tingkat provinsi. Sesuai panduan dari pemerintah, pendidikan Bahasa Inggris dapat dilakukan mulai kelas 4 SD. Mata pelajaran muatan lokal seperti pelajaran Bahasa Inggris di sekolah dasar merupakan wewenang sekolah, untuk menentukan apakah mata pelajaran Bahasa Inggris perlu diberikan di sekolahnya.

Pembelajaran bahasa Inggris di sekolah dasar selama ini masih bersifat konvensional. Dalam mengajar guru hanya mengandalkan metode ceramah secara klasikal. Guru kurang menggunakan media pendukung selain buku. Metode pembelajaran seperti ini kurang memenuhi prinsip-prinsip pembelajaran yang efektif dan kurang memberdayakan potensi siswa. Kegiatan belajar mengajar seharusnya mampu mengoptimalkan semua potensi siswa untuk menguasai kompetensi yang diharapkan. Proses belajar mengajar sebaiknya dilandasi dengan prinsip-prinsip: (1) berpusat pada siswa, (2) mengembangkan kreativitas siswa, (3) menciptakan kondisi menyenangkan dan menantang, (4) mengembangkan beragam kemampuan yang bermuatan nilai, (5) menyediakan pengalaman belajar yang beragam, dan (6) belajar melalui berbuat (Jurnal, Mardika:2008)

Untuk mencapai tujuan pembelajaran seperti yang telah diuraikan diatas, tidak bisa terlepas dari media pembelajaran yang merupakan bagian integral dari proses pembelajaran. Arsyad, (2011:15) mengungkapkan bahwa pemakaian media pembelajaran dalam proses belajar mengajar dapat membangkitkan keinginan dan minat yang baru, membangkitkan motivasi dan rangsangan kegiatan belajar, dan bahkan membawa pengaruh-pengaruh psikologis terhadap siswa. Maka untuk mencapai keberhasilan tersebut, guru sebaiknya tidak melupakan siswa untuk memanfaatkan semua alat indra yang dimilikinya. Artinya, dapat dilakukan dengan menampilkan rangsangan (stimulus) yang dapat diproses dengan berbagai indra. Semakin banyak indera yang digunakan untuk menerima dan mengelola pesan maka semakin besar kemungkinan pesan tersebut dimengerti dan diharapkan dapat menerima dan menyerap dengan mudah. Baik pesan-pesan dalam materi yang disajikan dalam sebuah media belajar (Arsyad, 2011:9).

Belajar dengan menggunakan indera ganda pandangan dan pendengaran berdasarkan konsep di atas akan memberikan keuntungan bagi siswa dikarenakan siswa akan lebih termotivasi dalam belajar, dibandingkan materi pelajaran yang hanya disampaikan dengan satu stimulus pandang atau dengar (Arsyad, 11:9). Tingkat keabstrakan jumlah jenis indera yang turut serta selama penerimaan isi pembelajaran sangat berperan besar dalam proses pembelajaran. Dikarenakan oleh pengalaman langsung akan memberikan kesan paling utuh dan paling bermakna mengenai informasi dan gagasan yang terkandung dalam pengelaman itu, hal ini terjadi karena melibatkan indera penglihatan, pendengaran,penciuman dan perabaan. Ini dikenal dengan learning by doing (Arsyad, 2011:11).

Hasil observasi yang dilakukan oleh peneliti (Nana, 2013) melalui tes angket terhadap 50 orang siswa kelas V sebagai sampel dan 15 orang guru di SD Swasta Sabilina Tembung menyatakan membutuhkan media pembelajaran dengan multimedia interaktif yang merupakan sumber belajar alternatif sebagai upaya dalam membantu proses pembelajaran yang lebih menarik untuk meningkatkan hasil belajar siswa. Media pembelajaran tersebut akan dikembangkan dalam bentuk CD (Compact Disk).

Belajar adalah suatu proses yang kompleks dan terjadi pada semua orang serta berlangsung seumur hidup Miarso (2004:550). Salah satu tanda seseorang telah belajar adalah adanya perubahan tingkahlaku dalam dirinya. Perubahan tingkahlaku tersebut menyangkut baik perubahan pengetahuan (kognitif) dan keterampilan (psikomotor) maupun yang menyangkut nilai dan sikap (afektif) (Sadiman, 2010:2). Menurut Budiningsih (2005:34) teori belajar kognitif lebih mementingkan proses belajar daripada hasil belajarnya. Teori ini berpandangan bahwa belajar merupakan suatu proses internal yang mencakup ingatan, retensi, 
pengolahan informasi, emosi dan aspek-aspek kejiwaan lainnya.

Proses belajar kognitif termasuk mengatur stimulus yang diterima dan menyesuaikannya dengan struktur kognitif yang sudah ada atau diperoleh berdasarkan pengalaman-pengalaman sebelumnya sehingga terjadi perubahan dalam tingkah laku. Dengan kata lain, belajar adalah perubahan persepsi dan pemahaman (Hamid, 2009:19). Pendapat Smaldino (2011:11) tentang belajar adalah merupakan pengembangan pengetahuan, ketrampilan, atau sikap yang baru ketika seseorang berinteraksi dengan informasi dan lingkungan.

Belajar dapat terjadi di rumah, di sekolah, di tempat kerja, di tempat ibadah, dan di masyarakat, serta berlangsung dengan cara apa saja, dari apa saja. Bahkan kemampuan orang untuk belajar ini merupakan salah satu ciri penting yang membedakan manusia dengan makhluk lain (Warsita, 2008:62). Belajar adalah suatu proses kompleks yang terjadi pada semua orang dan berlangsung seumur hidup, sejak masih bayi sampai ke liang lahat (Sadiman, dkk 2008: 62). Pada dasarnya terdapat dua (2) pendapat tentang teori belajar yaitu teori belajar aliran behavioristik dan teori belajar kognitif. Teori behavioristik mengatakan bahwa belajar adalah perubahan tingkah laku sebagai akibat dari adanya interaksi antara stimulus dan respon. Seseorang dianggap telah belajar jika dirinya telah mampu menunjukkan perubahan tingkah laku (Budiningsih, 2005:3).

Esensi dari teori konstruktivisme adalah ide bahwa siswa harus menemukan dan mentransformasikan suatu informasi kompleks ke situasi lain. Dalam The American Journal of Distance Education, Dongsong (2005) mengemukakan bahwa: "Conttuctivism emphasizes active participation and reflection by learners, who should control pace of instruction and construct knowledge by themselves" Sementara itu, konsep belajar menurut UNESCO adalah menuntut setiap satuan pendidikan untuk dapat mengembangkan empat pilar pendidikan baik untuk sekarang dan masa depan, yaitu: (1) learning to know (belajar untuk mengetahui), (2) learning to do (belajar untuk melakukan sesuatu) dalam hal ini kita dituntut untuk terampil dalam melakukan sesuatu, (3) learning to be (belajar untuk menjadi seseorang), dan (4) learning to live together (belajar untuk menjalani kehidupan bersama (Warsita, 2008: 63).
Pembelajaran adalah proses, cara menjadikan orang atau makhluk hidup belajar Amri (2013:230) pembelajaran adalah seperangkat tindakan yang dirancang untuk mendukung proses belajar siswa. Pembelajaran adalah membelajarkan siswa menggunakan asas pendidikan maupun teori belajar merupakan penentu utama keberhasilan pendidikan. Pembelajaran merupakan proses komunikasi dua arah antara guru dengan murid peserta didik (Sagala, 2006: 61). Sedangkan menurut Dimyati dan Mudjiono (1999: 297): Pembelajaran adalah suatu kegiatan secara terprogram dalam desain instruksional, untuk membuat siswa belajar secara aktif, yang menekankan pada penyediaan sumber belajar.

Dalam pembelajaran guru mempersiapkan segala kelengkapan pelajaran, baik dari materi, strategi, metode sampai dengan evaluasi pembelajaran. Kevin Riley (2006) menyatakan bahwa"

"The first step of this process is essential to the effectiveness of the serves learning project-during the first week of the course. The instructor established the learning environment by providing the subject with on overview of the project including goals, objectives, strategy, approach evaluation, and requirement to compete the learning process.

Bahasa adalah sesuatu yang paling berguna dan merupakan penemuan yang mengagumkan yang dicapai oleh manusia. Setiap bahasa mempunyai pola dan sistem yang sangat luas dan berbeda antar satu bahasa dengan bahasa lainnya. Mata pelajaran Bahasa Inggris bertujuan untuk: 1) mengembangkan kemampuan berkomunikasi dalam Bahasa Inggris, baik dalam bentuk lisan maupun tulisan yang meliputi kemampuan mendengarkan, berbicara, membaca dan menulis, 2) menumbuhkan kesadaran tentang hakikat bahasa dan pentingnya Bahasa Inggris sebagai salah satu bahasa asing untuk menjadi alat utama belajar, dan 3) mengembangkan pemahaman tentang saling keterkaitan antar bahasa dan budaya serta memperluas cakrawala budaya agar siswa memiliki wawasan lintas budaya dan dapat melibatkan diri dalam keragaman budaya (Depdiknas, 2004).

Ilmu Bahasa Inggris adalah sebuah ilmu yang mempelajari tata bahasa yang menggunakan Bahasa Inggris sebagai alat kominikasinya dan ilmu ini mengembangkan lisan maupun tulisan sebagai alat pembelajarannya. Ilmu Bahasa Inggris memiliki 
metode pembelajaran yang berupa listening (mendengarkan), speaking (berbicara), reading (membaca), dan writing (menulis).

Sudjana (2010:22) mendefinisikan hasil belajar siswa pada hakikatnya adalah perubahan tingkah laku dalam pengertian yang lebih luas mencakup bidang kognitif, afektif, dan psikomotorik. Hasil belajar adalah kemampuan yang dimiliki siswa setelah menerima pengalaman belajar yang ditentukan dengan menggunakan alat pengukuran yaitu berupa tes yang disusun secara terencana, baik tes tertulis, tes lisan maupun tes perbuatan.

Selanjutnya Dimyati dan Mudjiono (2013: 3) mengemukakan bahwa hasil belajar merupakan hasil dari suatu interaksi tindak belajar dan tindak mengajar. Penguasaan bahasa asing terutama Bahasa Inggris yang sedang dominan dalam pergaulan internasional, merupakan salah satu akses untuk meraih keberhasilan dalam berbagai bidang. Hal ini dikarenakan Bahasa Inggris mempunyai fungsi sebagai alat komunikasi dalam mengakses informasi, selain alat untuk membina hubungan interpersonal, bertukar informasi serta untuk estetika bahasa dalam budaya. Pelajaran Bahasa Inggris bertujuan sebagai berikut:

1. Mengembangkan kemampuan berkomunikasi dalam Bahasa Inggris, baik dalam bentuk lisan maupun tulisan, yang meliputi kemampuan mendengar (Listening), berbicara (Speaking), membaca (Reading), dan menulis (Writing).

2. Menumbuhkan kesadaran tentang hakikat bahasa dan pentingnya Bahasa Inggris sebagai salah satu bahasa asing untuk menjadi alat utama belajar.

3. Mengembangkan pemahaman tentang saling keterkaitan antar bahasa dan budaya antar negara serta memperluas cakrawala agar siswa memiliki wawasan lintas budaya dan dapat melibatkan diri dalam keragaman budaya antar negara.

Cameron (2001: 214) beranggapan bahwa anak usia SD berada pada masa pertumbuhan, perkembangan motorik, bahasa, sosial dan konseptualnya. Karena itu materi pembelajaran sebaiknya lebih dipusatkan pada pengembangan keterampilan berbahasa, kosakata, serta penggunaan bahasa pada tingkat wacana dengan metode pembelajaran yang interaktif seperti melalui games, lagu, rima, atau ceritera.

Secara sederhana, tenses bisa diartikan sebagai bentuk kata kerja yang menunjukkan waktu (Febriani, 2013:4) Tenses bisa juga diartikan sebagai salah satu jenis grammar yang menempatkan situasi atau tindakan dalam waktu, yang menunjukkan peristiwa yang sedang terjadi. Pendapat lainnya adalah pendapat (Jerry,2014:3) setiap bahasa mempunyai pola dasar yang sama dalam pembentukan sebuah kalimat. Pola tersebut adalah subject + predicate + object. Subject adalah pelaku, predicate berarti tindakan yang dilakukan subject, sedangkan object adalah yang dikenai pekerjaan.

Kata media berasal dari bahasa latin dan merupakan bentuk jamak dari kata medium yang secara harfiah berarti perantara atau pengantar. (Arsyad, 2011:3) Kata media didefinisikan dengan multi makna, berbagai macam definisi disebabkan adanya perbedaan dalam sudut pandang, maksud dan tujuan. AECT (Assosiaciation of Educational Communications Technology, 1977) memberi batasan tentang media sebagai segala bentuk dan saluran yang digunakan untuk menyampaikan pesan atau informasi. NEA (National Education Association) memaknai media adalah bentukbentuk komunikasi baik tercetak maupun audiovisual serta peralatannya. Media hendaknya dapat dimanipulasi, dapat dilihat, didengar dan dibaca. Namun, apapun batasan yang ada persamaan diantara batasan tersebut yaitu bahwa media adalah segala sesuatu yang dapat digunakan untuk menyalurkan pesan dari pengirim ke penerima pesan sehingga dapat merangsang pikiran, perasaan, perhatian dan minat serta perhatian siswa sedemikian rupa sehingga terjadi proses belajar tadi (Sadiman: 2010, 6-7). Hal tersebut juga sependapat dengan (Miarso,2009:457) yang menyatakan, "media pendidikan adalah berbagai jenis komponen dalam lingkungan siswa yang dapat merangsang siswa untuk belajar." Oleh karena itu (Miarso, 2009:457) menyebutkan, "media pembelajaran adalah sarana untuk memberikan perangsangan bagi si belajar supaya proses belajar terjadi". Sedangkan menurut Susilana (2009:7) menjelaskan bahwa, "media pembelajaran merupakan wadah dari pesan, dan materi yang ingin disampaikan adalah pesan pembelajaran, dengan tujuan mencapai proses pembelajaran."

Media Interaktif, yaitu media yang memungkinkan untuk berinteraksi. Melalui media ini siswa diajak untuk berinteraksi langsung dengan media ini. Siswa tidak hanya memerhatikan penyajian dan objek. Arsyad (2010:81-82) menguraikan prinsip-prinsip 
penggunaan media dan pengembangan media ke dalam: (1) media berbasis manusia (guru, instruktur, tutor, main peran, kegiatan kelompok, dan lain-lain), (2) media berbasis cetakan (buku, penuntun, buku kerja/latihan, dan lembaran lepas), (3) media berbasis visual (buku, charts, grafik, peta, figur/gambar, transparansi, slide), (4) media berbasis audio-visual (video, film, slide bersama tape, televisi), dan (5) media berbasis komputer (pengajaran dengan bantuan komputer dan video interaktif).

Rumusan masalah penelitian dan pengembangan ini adalah: (1) Apakah media pembelajaran tenses Bahasa Inggris berbasis multimedia interaktif yang dikembangkan layak digunakan untuk siswa kelas V SD Sabilina?; (2) Apakah media pembelajaran tenses Bahasa Inggris berbasis multimedia interaktif efektif pada pembelajaran siswa kelas V SD Sabilina?

\section{METODE}

Penelitian ini akan dilaksanakan di SD Swasta Sabilina Tembung berlokasi di Jalan Beringin Psr.VII Tengah, Tembung. Peneliti memilih lokasi ini karena masalah yang peneliti kemukakan sebelumnya terdapat di sekolah ini. Model pengembangan merupakan serangkaian prosedur dalam menghasilkan media pembelajaran. Model pengembangan yang digunakan dalam pengembangan media pembelajaran ini adalah model pengembangan Borg and Gall (2003: 775) yang dipadu dengan model pengembangan pembelajaran model Dick dan Carey (2005: 1).

Uji coba dimaksudkan untuk mengumpulkan data dalam rangka evaluasi formatif yang dijadikan dasar dalam menetapkan apakah produk telah layak digunakan dan juga menarik. Kegiatan yang akan dilakukan adalah sebagai berikut. Adapun tahapan-tahapannya adalah sebagai berikut: (1) Validasi ahli materi pembelajaran Bahasa Inggris; (2) Validasi ahli media pembelajaran; (3) Analisis konseptual; (4) Revisi pengembangan (tahap 1), berdasarkan penelitian yang berupa masukan, kritik atau saran dari 2 ahli materi, 2 ahli media pembelajaran dan 2 ahli perangkat lunak untuk dilakukan perbaikan; (5) Uji coba terhadap siswa (perorangan); (6) Analisis konseptual; (7) Revisi pengembangan (tahap II), berdasarkan penilaian yang berupa masukan, kritikan atau saran dari 3 siswa yang memiliki nilai tinggi, rendah dan sedang; (8) Uji coba kelompok kecil penilaian terhadap program ini berdasarkan angket yang telah diisi oleh 9 siswa; (9) Analisis konseptual dan produk; (10) Revisi produk (tahap III); (11) Uji coba lapangan; (12) Penilaian daya tarik dan kelayakan produk; (13) Analisis empirik (tahap IV); (14) Revisi kecil; dan (15 Uji efektifitas produk.

Analisis data dalam penelitian ini juga menggunakan analisis deskriptif kuantitatif. Semua data yang terkumpul dianalisis dengan teknik statistic deskriptif yang secara kuantitatif dipisahkan menurut kategori untuk mempertajam penilaian dalam menarik kesimpulan.

Kriterian software akan dikonversikan menjadi nilai dengan skala liniar menggunakan skala Likert yang dianalisis secara deskriptif persentase dengan rumus sebagai berikut (Sugiyono, 2011:134-136)

$$
\mathrm{X}=\frac{\text { Jumlahskoryangdiperoleh }}{\text { Jumlahskoridealseluruhitem }} \times 100 \%
$$

Dengan kriteria penilaian seperti yang tertulis pada table berikut ini:

Tabel 1. Kriteria Penilaian (Sugiyono, 2011:134-136)

\begin{tabular}{clc}
\hline Nilai & Kriteria & Persentase \\
\hline A & Sangat Layak & $81 \% \leq \times \leq 100 \%$ \\
\hline B & Layak & $61 \% \leq \times \leq \quad 80 \%$ \\
\hline C & Sedang & $41 \% \leq \times \leq 60 \%$ \\
\hline D & Kurang Layak & $21 \% \leq \times \leq 40 \%$ \\
\hline E & Sangat Kurang Layak & $0 \% \leq \times \leq 20 \%$ \\
\hline & & $X=$ Skor Empiris
\end{tabular}

Penelitian ini akan dilaksanakan di SD Sabilina Tembung berlokasi di Jalan Beringin Psr.VII Tengah Tembung. Sampel penelitian adalah sebagian dari populasi yang dianggap dapat mewakili dari seluruh populasi yang ada. Menurut Arikunto (2009: 134) adalah "apabila subjeknya kurang dari 100 maka lebih baik diambil semua sehingga penelitiannya merupakan penelitian populasi”. Selanjutnya jika jumlah subjeknya besar dapat diambil 10$15 \%$ atau $20-25 \%$ atau lebih".

Berdasarkan pendapat diatas, karena populasi dalam penelitian ini berjumlah $<$ dari 100, maka yang menjadi sampel dalam 
penelitian ini adalah keseluruhan populasi atau total sampling. Dimana kelas A sebagai kelas eksperimen dan kelas B sebagai kelas kontrol. sebagai berikut :

Langkah-langkah teknik analisa data

\section{Nilai Rata-rata}

Untuk menentukan nilai rata-rata digunakan rumus:

$$
\bar{x}=\sum x \quad \text { (Sudjana, 2002: 67) }
$$

\section{Standar Deviasi}

Untukmenentukan Standa

Deviasi digunakan rumus yaitu,

$$
s=\sqrt{\frac{\sum(x i-\bar{x})^{2}}{n-1}} \quad \text { (Sudjana, 2002:93) }
$$

Dimana: $s=$ Standar Deviasi

$$
\begin{aligned}
& x i=\text { Harga Data ke-i } \\
& n=\text { Jumlah Sempel }
\end{aligned}
$$

\section{Uji Normalitas}

Uji normalitas data menggunakan teknik Lilliefors. Langkah-langkah yang digunakan adalah sebagai berikut:

a. Data hasil belajar $x_{1}, x_{2}, \ldots, \ldots, x_{\mathrm{n}}$ dijadikan bilangan baku $\mathrm{z}_{1}, \quad \mathrm{z}_{2}, \ldots, \ldots, \quad \mathrm{z}_{\mathrm{n}}$ dengan menggunakan rumus : $Z_{l}=\frac{X 1-\bar{X}}{S}$

(Sudjana, 2002: 99).

Dimana:

$\bar{x}=$ Nilai rata-rata hitung

$\mathrm{S}=$ Simpangan baku

b. Untuk tiap bilangan baku ini menggunakan daftar distribusi normal baku, kemudian dihitung peluang $\mathrm{F}\left(\mathrm{Z}_{1}\right)=\mathrm{P}\left(\mathrm{z} \leq \mathrm{Z}_{\mathrm{i}}\right)$

c. Menghitung proporsi $S \quad\left(\mathrm{z}_{\mathrm{i}}\right)=$ $\frac{\text { banyaknya } Z 1, Z 2, \ldots, \ldots, Z n \leq Z i}{n}$

d. Hitung selisih $F\left(z_{i}\right)-S\left(z_{i}\right)$ kemudian tentukan harga mutlaknya.

e. Menentukan harga terbesar dari selisih harga mutlak $\mathrm{F}\left(\mathrm{Z}_{\mathrm{i}}\right)$ - $\mathrm{S}\left(\mathrm{zi}_{\mathrm{i}}\right)$ sebagai $\mathrm{L}_{\mathrm{o}}$. Untuk menerima atau menolak distribusi normal dan penelitian dapat dibandingkan $\mathrm{L}_{\text {hitung }}$ dengan nilai kritis $L_{\text {tabel }}$ yang diambil dari daftar table uji lilliefors dengan taraf $a=$ $5 \%$.

Kriteria pengujian :

Jika $\mathrm{L}_{\text {hitung }}<\mathrm{L}_{\text {tabel }}$ maka sampel

berdistribusi normal.

Jika $\mathrm{L}_{\text {hitung }}>\mathrm{L}_{\text {tabel }}$ maka sampel tidak berdistribusi normal.

\section{Uji Homogenitas}

Uji Homogenitas varians dihitung dengan besar menggunakan uji $\mathrm{F}$ yaitu:

$$
F=\quad \frac{\text { Varians Terbesar }}{\text { Varians Terkecil }} \text { atau } F=\frac{S 1^{2}}{S 2^{2}}
$$

Dimana:
$S_{1}^{2}=$ Varians dari kelompok yang lebih besar

$S_{2}{ }^{2}=$ Varians dari kelompok kecil

Kriteria pengujian:

Jika $F_{\text {hitung }}<\mathrm{F}_{\text {tabel }}$ maka sampel mempunyai Varians yang sama.

Jika $F_{\text {hitung }} \mathrm{F}_{\text {tabel }}$ maka sampel tidak mempunyai Varians yang sama.

\section{Pengujian Hipotesis}

Hipotesis penelitian yang diuji adalah:

$\mathrm{H}_{\mathrm{o}}: \mu_{1}=\mu_{2}$

$\mathrm{H}_{\mathrm{a}}: \mu_{1}>\mu_{2}$

Keterangan:

$\mu_{1}$ : Rata-rata hasil belajar siswa yang diajar menggunakan media pembelajaran interaktif.

$\mu_{2}$ : Rata-rata hasil belajar siswa yang diajar dengan pembelajaran konvensional.

$\mathrm{H}_{\mathrm{o}} \quad$ : Tidak ada perbedaaan hasil belajar bahasa Inggris siswa yang diajar dengan menggunakan media pembelajaran berbasis multimedia interaktif lebih tinggi dan siswa yang diajar dengan

pembelajaran yang tidak berbasis multimedia interaktif.

$\mathrm{H}_{\mathrm{a}}$ : Ada perbedaan hasil belajar bahasa Inggris siswa yang diajar dengan menggunakan media pembelajaran berbasis multimedia interaktif lebih tinggi dari siswa yang diajar dengan pembelajaran tidak berbasis multimedia interaktif.

Untuk uji hipotesis digunakan rumus uji dua pihak:

$$
t=\frac{\bar{x}_{1}-\bar{x}_{2}}{\sqrt[s]{\frac{1}{n_{1}}+\frac{1}{n_{2}}}}
$$

(Sudjana, 2002:239)

Dimana $\mathrm{S}$ adalah akar varians gabungan yang dihitung dengan rumus :

$$
S^{2}=\frac{\left(n_{1}-1\right) s_{1}^{2}+\left(n_{2}-1\right) s_{2}^{2}}{n_{1}+n_{2}-2}
$$

Dimana $S=\sqrt{S^{2}}$

Dimana:

$t=$ Harga perhitungan

$\mathrm{n}_{1}=$ Jumlah sampel kelas eksperimen

$\bar{x}_{1}=$ Skor rata-rata kelas eksperimen

$\mathrm{n}_{2}=$ Jumlah sampel kelas control

$x_{2}=$ Skor rata-rata kelas control

$S=$ varians gabungan

$S 1^{2}=$ varians kel. kelas eksperimen

$S 2^{2}=$ varians kel. kelas control

Kriteria pengujian terima Ha jika $t_{\text {hitung }}>t_{\text {tabel }}$ yang didapat dari daftar distribusi dengan:

$\mathrm{dk}=(\mathrm{n}-1)$ dan taraf $\alpha=5 \%$

Untuk melihat nilai keefektifan media pembelajaran interaktif yang dieksperimen 
digunakan rumus perhitungan efektifitas berikut (Sugiono, 20011:415-418) yaitu:

$\mathrm{X}=\frac{\text { Jumlah skor yang diperoleh }}{\text { Jumlah skor ideal seluruh item }} \times 100 \%$

HASIL DAN PEMBAHASAN

Hasil

Tabel 2. Skor Penilaian Media Pembelajaran Multimedia Interaktif Oleh Ahli Materi Tentang Kualitas Materi Pembelajaran (Skala 1-5)

\begin{tabular}{llccccc}
\hline \multirow{2}{*}{ No } & \multicolumn{1}{c}{ Indikator Penilaian } & \multicolumn{2}{c}{ Responden } & Jumlah & \multirow{2}{*}{ Rata- rata } & Kriteria \\
\cline { 2 - 7 } & & 1 & 2 & Skor & & \\
\hline 1 & Kejelasan tujuan pembelajaran & 4 & 5 & 9 & $90,00 \%$ & Sangat Layak \\
\hline 2 & Ketepatan cakupan materi & 4 & 5 & 9 & $90,00 \%$ & Sangat Layak \\
\hline 3 & Kualitas soal-soal latihan & 4 & 5 & 9 & $90,00 \%$ & Sangat Layak \\
\hline 4 & $\begin{array}{l}\text { Ketercernaan materi dan pemaparan } \\
\text { yang logis }\end{array}$ & 4 & 5 & 9 & $90,00 \%$ & Sangat Layak \\
\hline 5 & Penggunaan bahasa & 4 & 4 & 8 & $80,00 \%$ & Layak \\
\hline 6 & Kemudahan pemahaman instruksi & 4 & 5 & 9 & $90,00 \%$ & Sangat Layak \\
\hline 7 & Perwajahan & 4 & 5 & 9 & $90,00 \%$ & Sangat Layak \\
\hline 8 & Ilustrasi & 4 & 5 & 9 & $90,00 \%$ & Sangat Layak \\
\hline \multicolumn{2}{c}{$\quad$ Rata-rata } & & & & $\mathbf{8 8 , 7 5 \%}$ & Sangat Layak \\
\hline
\end{tabular}

Tabel 3. Skor Penilaian Media Pembelajaran Multimedia Interaktif Oleh Ahli Materi Tentang Kualitas Strategi Pembelajaran (Skala 1-5)

\begin{tabular}{lllcccc}
\hline \multirow{2}{*}{ No } & \multicolumn{1}{c}{ Indikator Penilaian } & \multicolumn{2}{c}{ Responden } & Jumlah & $\begin{array}{c}\text { Rata- } \\
\text { rata }\end{array}$ & Kriteria \\
\cline { 2 - 5 } 1 & Kualitas pendahuluan & 4 & 4 & 8 & $80,00 \%$ & Layak \\
\hline 2 & Kualitas penyajian materi & 4 & 4 & 8 & $80,00 \%$ & Layak \\
\hline 3 & $\begin{array}{l}\text { Keterlibatan dan peran peserta } \\
\text { didik dalam aktivitas belajar }\end{array}$ & 4 & 4 & 8 & $80,00 \%$ & Layak \\
& & & & & \\
\hline 4 & Kualitas umpan balik & 4 & 4 & 8 & $80,00 \%$ & Layak \\
\hline 5 & Waktu penyajian & 4 & 4 & 8 & $80,00 \%$ & Layak \\
\hline & Rata-rata & & & & $\mathbf{8 0 , 0 0 \%}$ & Layak \\
\hline
\end{tabular}

Tabel 4. Skor Penilaian Media Pembelajaran Multimedia Interaktif Oleh Ahli Materi Tentang Sistem Penyampaian Pembelajaran (Skala1-5)

\begin{tabular}{|c|c|c|c|c|c|c|}
\hline \multirow{2}{*}{ No } & \multirow{2}{*}{ Indikator Penilaian } & \multicolumn{2}{|c|}{ Responden } & \multirow{2}{*}{$\begin{array}{l}\text { Jumlah } \\
\text { Skor }\end{array}$} & \multirow{2}{*}{ Rata-rata } & \multirow{2}{*}{ Kriteria } \\
\hline & & 1 & 2 & & & \\
\hline 1 & Kebenaran konsep & 4 & 4 & 8 & $80,00 \%$ & Sangat Layak \\
\hline 2 & $\begin{array}{l}\text { Kedalaman materi } \\
\text { pembelajaran }\end{array}$ & 4 & 4 & 8 & $80,00 \%$ & Layak \\
\hline 3 & $\begin{array}{l}\text { Kesesuaian dengan } \\
\text { kurikulum }\end{array}$ & 4 & 5 & 9 & $90,00 \%$ & Sangat Layak \\
\hline \multirow[t]{2}{*}{4} & $\begin{array}{l}\text { Ketepatan urutan materi } \\
\text { pembelajaran }\end{array}$ & 4 & 4 & 8 & $80,00 \%$ & Sangat Layak \\
\hline & Rata-rata & & & & $82,50 \%$ & Sangat Layak \\
\hline
\end{tabular}

\section{Analisis Data Hasil Evaluasi Ahli Materi}

Keseluruhan hasil penilaian yang diberikan oleh ahli materi pada aspek aspek yang dinilai diperoleh skor rata-rata pada kategori masing-masing. Hasil penilaian tersebut dianalisis untuk menentukan layak tidaknya dilakukan pengembangan terhadap media pembelajaran interaktif pada 
mata pelajaran Bahasa Inggris. Adapun persentase rata-rata dari hasil penilaian ahli materi dapat dilihat pada Tabel 4.9 berikut:

Tabel 5. Persentase Rata-Rata Hasil Penilaian Terhadap Media Pembelajaran Bahasa Inggris Berbasia Multimedia Interaktif Oleh Ahli Materi

\begin{tabular}{clcl}
\hline No & \multicolumn{1}{c}{ Kategorisasi } & Persentase Rata-rata & \multicolumn{1}{c}{ Kriteria } \\
\hline 1. & Aspek materi pembelajaran & $88,75 \%$ & Sangat Layak \\
\hline 2. & Aspek strategi pembelajaran & $80,00 \%$ & Layak \\
\hline 3. & $\begin{array}{l}\text { Aspek sistem penyampaian } \\
\text { pembelajaran }\end{array}$ & $82,25 \%$ & Sangat Layak \\
\hline \multicolumn{2}{c}{ Rata-rata } & $\mathbf{8 5 , 5 3 \%}$ & Sangat Layak
\end{tabular}

\section{Data Hasil Validasi Ahli Desain Pembelajaran}

Tabel 6. Skor Penilaian Media Pembelajaran Interaktif Oleh Ahli Desain Pembelajaran Tentang Aspek Kualitas Desain Pembelajaran (Skala 1-5)

\begin{tabular}{llccccc}
\hline \multirow{2}{*}{ No } & \multirow{2}{*}{ Indikator Penilaian } & \multicolumn{2}{c}{ Responden } & Jumlah & & Kriteria \\
\cline { 2 - 6 } & 1 & 2 & Skor & Rata-rata & \\
\hline 1 & Ketepatan pemilihan topic & 4 & 5 & 9 & $90,00 \%$ & Sangat Layak \\
\hline 2 & $\begin{array}{l}\text { Kesesuaian materi dengan indikator } \\
\text { pembelajaran }\end{array}$ & 5 & 5 & 10 & $100,00 \%$ & Sangat Layak \\
\hline 3 & Pemberian latihan & 4 & 5 & 9 & $90,00 \%$ & Sangat Layak \\
\hline 4 & $\begin{array}{l}\text { Konsistensi Tes dengan indikator } \\
\text { pembelajaran }\end{array}$ & 5 & 5 & 10 & $100,00 \%$ & Sangat Layak \\
\hline Rata-rata & & & & $\mathbf{9 5 , 0 0 \%}$ & Sangat Layak \\
\hline
\end{tabular}

Tabel 7. Skor Penilaian Media Pembelajaran Interaktif Oleh Ahli Desain Pembelajaran Tentang Aspek Kualitas Desain Informasi (Skala 1-5)

\begin{tabular}{|c|c|c|c|c|c|c|}
\hline \multirow[b]{2}{*}{ No } & \multirow[b]{2}{*}{ Indikator Penilaian } & \multicolumn{2}{|c|}{ Responden } & \multirow{2}{*}{$\begin{array}{l}\text { Jumla } \\
\text { h Skor }\end{array}$} & \multirow[b]{2}{*}{ Rata-rata } & \multirow[b]{2}{*}{ Kriteria } \\
\hline & & 1 & 2 & & & \\
\hline 1 & Pemberian motivasi & 5 & 4 & 9 & $90,00 \%$ & Sangat Layak \\
\hline 2 & Kejelasan Uraian Materi & 5 & 5 & 10 & $100,00 \%$ & Sangat Layak \\
\hline 3 & Kejelasan contoh yang diberikan & 5 & 5 & 10 & $100,00 \%$ & Sangat Layak \\
\hline 4 & Penggunaan informasi baru & 5 & 4 & 9 & $90,00 \%$ & Sangat Layak \\
\hline 5 & $\begin{array}{l}\text { Umpan balik terhadap hasil tes } \\
\text { peserta didik }\end{array}$ & 4 & 5 & 9 & $90,00 \%$ & Sangat Layak \\
\hline 6 & Pembabakan/sekuensial & 5 & 4 & 9 & $90,00 \%$ & Sangat Layak \\
\hline 7 & Pemaksimalan proses pembelajaran & 4 & 4 & 8 & 80,00 & Layak \\
\hline 8 & Kemudahan penggunaan & 5 & 5 & 10 & $100,00 \%$ & Sangat Layak \\
\hline & Rata-rata & & & & $\mathbf{9 2 , 5 0 \%}$ & Sangat Layak \\
\hline
\end{tabular}

Tabel 8. Skor Penilaian Media Pembelajaran Interaktif Oleh Ahli Desain Pembelajaran Tentang Aspek Kualitas Desain Interaksi (Skala 1-5)

\begin{tabular}{llccccc}
\hline \multirow{2}{*}{ No Indikator Penilaian } & \multicolumn{2}{c}{ Responden } & Jumlah & \multirow{2}{*}{ Rata-rata } & \multirow{2}{*}{ Kriteria } \\
\cline { 2 - 7 } & & 1 & 2 & Skor & & \\
\hline 1 & Penggunaan petunjuk belajar & 4 & 5 & 9 & $90,00 \%$ & Sangat Layak \\
\hline 2 & Penjelasan istilah & 5 & 4 & 9 & $90,00 \%$ & Sangat Layak \\
\hline 3 & Umpan balik terhadap respon peserta didik & 4 & 5 & 8 & $90,00 \%$ & Layak \\
\hline 4 & $\begin{array}{l}\text { Penggunaan teks yang berbeda untuk } \\
\text { menandai yang penting }\end{array}$ & 5 & 5 & 10 & $100,00 \%$ & Sangat Layak \\
\hline & & & & $\mathbf{9 0 , 0 0 \%}$ & Sangat Layak \\
\hline
\end{tabular}


Tabel 9. Skor Penilaian Media Pembelajaran Interaktif Oleh Ahli Desain embelajaran Tentang Aspek Kualitas Presentasi (Skala 1-5)

\begin{tabular}{|c|c|c|c|c|c|c|}
\hline \multirow[b]{2}{*}{ No } & \multirow[b]{2}{*}{ Indikator Penilaian } & \multicolumn{2}{|c|}{ Responden } & \multirow{2}{*}{$\begin{array}{c}\text { Jumlah } \\
\text { Skor }\end{array}$} & \multirow[b]{2}{*}{ Rata-rata } & \multirow[b]{2}{*}{ Kriteria } \\
\hline & & 1 & 2 & & & \\
\hline 1 & Komposisi warna & 5 & 4 & 9 & $90,00 \%$ & Sangat Layak \\
\hline 2 & Penggunaan grafis & 5 & 4 & 9 & $90,00 \%$ & Sangat Layak \\
\hline 3 & Pemilihan jenis dan ukuran font & 5 & 4 & 9 & $90,00 \%$ & Sangat Layak \\
\hline 4 & Penggunaan tombol navigasi & 5 & 4 & 10 & $90,00 \%$ & Sangat Layak \\
\hline 5 & Kualitas gambar dan animasi & 5 & 4 & 10 & $90,00 \%$ & Sangat Layak \\
\hline 6 & Penggunaan musik & 5 & 4 & 10 & $90,00 \%$ & Sangat Layak \\
\hline & Rata-rata & & & & $98,33 \%$ & Sangat Layak \\
\hline
\end{tabular}

\section{Analisis Data Hasil Evaluasi Ahli Desain Pembelajaran}

Hasil penilaian dari ahli desain pembelajaran terhadap aspek desain pembelajaran diperoleh skor rata-rata pada kategori masing-masing. Hasil penilaian tersebut dianalisis untuk menentukan layak tidaknya dilakukan pengembangan terhadap media pembelajaran interaktif pada mata pelajaran Bahasa Inggris.

Tabel 10. Persentase Rata-Rata Hasil Penilaian Terhadap Media Pembelajaran Bahasa Inggris Berbasis Multimedia Interaktif Oleh Ahli Desain Pembelajaran

\begin{tabular}{clcl}
\hline No & \multicolumn{1}{c}{ Kategorisasi } & Persentase Rata-rata & \multicolumn{1}{c}{ Kriteria } \\
\hline 1 & Kualitas desain pembelajaran & $95,00 \%$ & Sangat Layak \\
\hline 2 & Kualitas desain informasi & $92,50 \%$ & Sangat Layak \\
\hline 3 & Kualitas desain interaksi & $90,00 \%$ & Sangat Layak \\
\hline 4 & Kualitas Desain Presentasi & $98,33 \%$ & Sangat Layak \\
\hline & Rata-rata & $\mathbf{9 3 , 9 6 \%}$ & Sangat Layak \\
\hline
\end{tabular}

\section{Ahli Rekayasa Perangkat Lunak}

Hasil validasi dari kedua ahli rekayasa perangkat lunak berupa skor penilaian terhadap media pembelajaran interaktif mata pelajaran Bahasa Inggris pada aspek pemrograman dapat dinilai pada Tabel 11.

Tabel 11. Skor Penilaian Media Pembelajaran Interaktif Oleh Ahli Rekayasa Perangkat Lunak dan Desain Grafis Pada Aspek Pemrograman (Skala 1-5)

\begin{tabular}{|c|c|c|c|c|c|c|}
\hline \multirow[b]{2}{*}{ No } & \multirow[b]{2}{*}{ Indikator Penilaian } & \multicolumn{2}{|c|}{ Responden } & \multirow{2}{*}{$\begin{array}{c}\text { Jumlah } \\
\text { Skor }\end{array}$} & \multirow[b]{2}{*}{ Rata-rata } & \multirow[b]{2}{*}{ Kriteria } \\
\hline & & 1 & 2 & & & \\
\hline 1 & Perintah eksekusi & 4 & 5 & 9 & $90,00 \%$ & Sangat Layak \\
\hline 2 & $\begin{array}{lll}\begin{array}{l}\text { Konsistensi dengan } \\
\text { program }\end{array} & \text { alur } \\
\end{array}$ & 4 & 4 & 8 & $80,00 \%$ & Layak \\
\hline 3 & Keberlanjutan program & 4 & 4 & 8 & $80,00 \%$ & Layak \\
\hline 4 & Efisiensi sistem & 4 & 5 & 9 & $90,00 \%$ & Sangat Layak \\
\hline 5 & Ketepatan display & 4 & 5 & 9 & $90,00 \%$ & Sangat Layak \\
\hline 6 & Pengelolaan disc & 4 & 4 & 8 & $80,00 \%$ & Layak \\
\hline 7 & $\begin{array}{lll}\begin{array}{l}\text { Konsistensi antar bagian } \\
\text { pelajaran }\end{array} & \\
\end{array}$ & 4 & 5 & 9 & $90,00 \%$ & Sangat Layak \\
\hline 8 & Modifikasi yang mudah & 4 & 5 & 9 & $90,00 \%$ & Sangat Layak \\
\hline & Rata-rata & & & & $86,25 \%$ & Sangat Layak \\
\hline
\end{tabular}

\section{Analisis Data Hasil Evaluasi Ahli Rekayasa Perangkat Lunak}

Keseluruhan hasil penilaian yang diberikan oleh ahli rekayasa perangkat lunak pada setiap aspek, ditentukan oleh skor rata-rata pada kategorinya masing-masing. Hasil penilaian tersebut 
dianalisis untuk menentukan layak tidaknya dilakukan pengembangan terhadap media pembelajaran interaktif mata pelajaran Bahasa Inggris.

Tabel 12. Persentase Rata-Rata Hasil Penilaian Terhadap Media Pembelajaran Interaktif Mata Pelajaran Bahasa Inggris Oleh Ahli Rekayasa Perangkat Lunak.

\begin{tabular}{clcc}
\hline No & \multicolumn{1}{c}{ Kategorisasi } & Persentase Rata-rata & Kriteria \\
\hline 1 & Pemprograman & $86,25 \%$ & Sangat Layak \\
\hline 2 & Kualitas teknis/tampilan & $87,14 \%$ & Sangat Layak \\
\hline & Rata-rata & $\mathbf{8 8 , 9 9 \%}$ & Sangat Layak \\
\hline
\end{tabular}

Uji coba lapangan dilakukan terhadap kelas V SD Swasta Sabilina. Hasil uji coba lapangan dijadikan data untuk mengukur kelayakan dari produk yang dikembangkan, sekaligus untuk mengetahui sampai sejauh mana manfaat produk tersebut bagi hasil belajar pemakainya.

Tabel 13. Skor Penilaian Media Pembelajaran Bahasa Inggris Berbasis Multimedia Interaktif pada Uji Coba Lapangan Pada Aspek Kualitas Materi Pembelajaran

\begin{tabular}{|c|c|c|c|c|c|c|c|c|}
\hline \multirow{2}{*}{ No } & \multirow{2}{*}{ Indikator Penilaian } & \multicolumn{5}{|c|}{ Skor } & \multirow{2}{*}{ Rata-rata } & \multirow{2}{*}{ Kriteria } \\
\hline & & 1 & 2 & 3 & 4 & 5 & & \\
\hline 1 & Kesesuaian materi & & & & 12 & 38 & $96,89 \%$ & Sangat Layak \\
\hline 2 & Kejelasan petunjuk belajar & & & & 15 & 35 & $95,56 \%$ & Sangat Layak \\
\hline 3 & $\begin{array}{l}\text { Kemudahan memahami } \\
\text { kalimat pada teks }\end{array}$ & & & & 12 & 39 & $97,33 \%$ & Sangat Layak \\
\hline 4 & $\begin{array}{l}\text { Kemudahan memahami } \\
\text { pembelajaran }\end{array}$ & & & & 17 & 33 & $94,67 \%$ & Sangat Layak \\
\hline 5 & Ketepatan urutan penyajian & & & & 13 & 37 & $96,44 \%$ & Sangat Layak \\
\hline 6 & Kecukupan latihan & & & & 5 & 45 & $97,78 \%$ & Sangat Layak \\
\hline 7 & Kejelasan umpan balik & & & & 3 & 47 & $98,67 \%$ & Sangat Layak \\
\hline 8 & $\begin{array}{l}\text { Bantuan belajar dengan } \\
\text { program }\end{array}$ & & & & 4 & 46 & $98,22 \%$ & Sangat Layak \\
\hline & Rata-rata & & & & & & $96,95 \%$ & Sangat Layak \\
\hline
\end{tabular}

Tabel 14. Skor Penilaian Media Pembelajaran Bahasa Inggris Berbasis Multimedia Interaktif Pada Uji Coba Lapangan Pada Aspek Kualitas Teknis/Tampilan

\begin{tabular}{|c|c|c|c|c|c|c|c|}
\hline \multirow[b]{2}{*}{ No } & Indikator Penilaian & \multicolumn{4}{|c|}{ Skor } & \multirow{2}{*}{ Rata-rata } & \multirow{2}{*}{ Kriteria } \\
\hline & 1 & 2 & 3 & 4 & 5 & & \\
\hline 1 & Keindahan tampilan layar & & & 10 & 37 & $94,67 \%$ & Sangat Layak \\
\hline 2 & Keterbacaan teks & & & 18 & 32 & $92,00 \%$ & Sangat Layak \\
\hline 3 & Kualitas gambar dan animasi & & & 20 & 30 & $93,33 \%$ & Sangat Layak \\
\hline 4 & Komposisi warna & & & 21 & 29 & $90,67 \%$ & Sangat Layak \\
\hline 5 & Navigasi & & & 23 & 27 & $92,00 \%$ & Sangat Layak \\
\hline 6 & Daya dukung music & & & 18 & 32 & $96,00 \%$ & Sangat Layak \\
\hline 7 & Interaksi & & & 10 & 40 & $96,89 \%$ & Sangat Layak \\
\hline & Rata-rata & & & & & $93,65 \%$ & Sangat Layak \\
\hline
\end{tabular}

Tabel 15. Persentase Rata-Rata Hasil Penilaian Terhadap Media Pembelajaran Bahasa Inggris Berbasis Multimedia Interaktif Pada Uji Coba Lapangan

\begin{tabular}{cccc}
\hline No & Kategorisasi & Persentase rata-rata & Kriteria \\
\hline 1 & Aspek kualitas materi pembelajaran & $96,95 \%$ & Sangat Layak \\
\hline 2 & Aspek kualitas teknis/tampilan & $93,65 \%$ & Sangat Layak \\
\hline & Rata-rata & $\mathbf{9 5 , 3 0 \%}$ & Sangat Layak \\
\hline
\end{tabular}

Adapun rangkuman persentase rata-rata hasil penilaian terhadap media pembelajaran interaktif mata pelajaran Bahasa Inggris oleh ahli materi, ahli desain pembelajaran, ahli rekayasa 
perangkat lunak, uji coba perorangan, uji coba kelompok kecil dan uji coba lapangan dapat dilihat pada Tabel 4.49 berikut ini:

Tabel 16. Rangkuman Persentase Rata-Rata Hasil Penilaian Terhadap Media Pembelajaran Bahasa Inggris Berbasis Multimedia Interaktif

\begin{tabular}{llcc}
\hline No & \multicolumn{1}{c}{ Responden } & Persentase Rata-rata & Kriteria \\
\hline 1 & Ahli materi & $80,53 \%$ & Sangat Baik \\
\hline 2 & Ahli desain pembelajaran & $84,38 \%$ & Baik \\
\hline 3 & Ahli rekayasa perangkat lunak & $73,90 \%$ & Baik \\
\hline 4 & Siswa pada uji coba perorangan & $91,37 \%$ & Sangat Baik \\
\hline 5 & Siswa pada uji coba kelompok kecil & $94,82 \%$ & Sangat Baik \\
\hline 6 & Siswa pada uji coba lapangan & $95,30 \%$ & Sangat Baik \\
\hline & Rata-Rata & $\mathbf{8 9 , 6 1 \%}$ & Sangat Baik \\
\hline
\end{tabular}

\section{Hipotesis II}

\section{Uji t Pre-Test}

Hipotesis yang diajukan pada penelitian ini adalah kelayakan dari media pembelajaran multimedia interaktif. Setelah uji kelayakan data selesai dilakukan maka selanjutnya dilakukan uji t pre-test penelitian. Hal ini dilakukan untuk mengetahui apakah terdapat perbedaan kemampuan awal kelas kontrol dan kelas eksperimen dengan menggunakan uji t pre-test. Berdasarkan hasil perhitungan pada diperoleh output $t_{\text {hitung }}$ sebesar -2,31 dan $t_{\text {tabel }}$ sebesar 1,67 pada taraf kepercayaan 95 persen. Maka diperoleh bahwa $t_{\text {hitung }}<\mathrm{t}_{\text {tabel }}$ atau $-2,31<1,67$ atau dengan kata lain $\mathrm{Ha}$ ditolak. Hal ini menunjukkan bahwa kemampuan awal siswa sesuai kelas kontrol dan kelas eksperimen adalah cenderung sama dan tidak berbeda secara signifikan.

Uji t Post-Test

Hipotesis yang diajukan pada penelitian ini adalah terdapat perbedaan yang signifikan antara hasil belajar siswa yang dibelajarkan dengan penggunaan media pembelajaran interaktif dengan hasil belajar siswa yang dibelajarkan tanpa menggunaan media pembelajaran interaktif. Adapun Rumus yang digunakan untuk uji hipotesis adalah uji-t. Kefektifan tanpa media pembelajaran interaktif diperoleh dengan perhitungan sebagai berikut:

$$
X(a)=\frac{\text { jumlah skor yang diperoleh }}{\text { jumlah skor ideal }} \times 100 \%
$$

Efektifitas $=\frac{3410}{3750} \times 100 \%=90 \%$

Sedangkan untuk nilai keefektifan media pembelajaran yang menggunakan media interaktif sebesar $95,63 \%$ yang diperoleh dengan perhitungan sebagai berikut:

$$
\begin{aligned}
& X(b)=\frac{\text { jumlah skor yang diperoleh }}{\text { jumlah skor ideal }} \times 100 \% \\
& \text { Efektifitas }=\frac{3586}{3750} \times 100 \%=95,63 \%
\end{aligned}
$$

Dari hasil perhitungan efektifitas diatas, diperoleh data bahwa hasil belajar siswa yang dibelajarkan dengan penggunaan media pembelajaran interaktif $X(b)=95,63 \%)$ lebih tinggi dari hasil belajar siswa yang dibelajarkan tanpa meggunaan media pembelajaran interaktif $X(a)=90 \%)$. Hasil pengolahan, data diperoleh $t_{\text {hitung }}$ sebesar 9,27 sedangkan $t_{\text {tabel }}$ pada $\alpha=0,05$ dengan derajat kebebasan 98 adalah: 1,98. Karena $t_{\text {hitung }}(9,27)$ lebih besar dari $t_{\text {tabel }}(1,98)$. Berdasarkan pengolahan data yang diperoleh maka dapat disimpulkan bahwa ada perbedaan yang signifikan antara hasil belajar siswa yang dibelajarkan dengan penggunaan media pembelajaran interaktif dan hasil belajar siswa yang dibelajarkan tanpa menggunaan media pembelajaran interaktif.

\section{PENUTUP}

Berdasarkan rumusan masalah, tujuan, hasil dan pembahasan penelitian pengembangan media pembelajaran tenses Bahasa Inggris berbasis multimedia interaktif yang dikemukakan sebelumnya maka dapat disimpulkan sebagai berikut: 1. Penggunaan media pembelajaran interaktif pada tes hasil belajar siswa menunjukkan bahwa hasil belajar siswa yang dibelajarkan dengan menggunakan media pembelajaran interaktif (kelas eksperimen) lebih tinggi $=69-76$ dari hasil belajar siswa yang dibelajarkan tanpa menggunakan media pembelajaran interaktif (kelas kontrol) $=60-69$. Dengan demikian disimpulkan bahwa terdapat perbedaan yang signifikan antara hasil belajar siswa yang dibelajarkan dengan menggunakan media pembelajaran interaktif dengan hasil belajar siswa yang dibelajarkan tanpa menggunakan media pembelajaran interaktif, dimana diperoleh $t_{\text {hitung }}$ sebesar $t_{\text {hitung }}$ sebesar 9,0229, sedangkan 
$\mathrm{t}_{\text {tabel }}$ pada $\alpha=0,05$ dengan derajat kebebasan 94 adalah: 1,98. Hal ini menunjukan bahwa media pembelajaran interaktif memiliki kelayakan yang dapat meningkatkan hasil belajar siswa dalam pembelajaran tenses Bahasa Inggris.

2. Berdasarkan pengggunaan media pembelajaran interaktif pada hasil tes belajar siswa yang diperlihatkan pada point diatas, ditemukan bahwa media pembelajaran interaktif memiliki keefektifan sebesar 95,63\% lebih tinggi dari keefektifan tanpa media pembelajaran interaktif 90\%. Dari hasil ini dapat disimpulkan bahwa media pembelajaran interaktif lebih efektif dibandingkan pembelajaran tanpa media pembelajaran interaktif tenses Bahasa Inggris

\section{DAFTAR PUSTAKA}

Arsyad, Azhar.2011. Media Pembelajaran. Jakarta: Rajawali Pers.

Ardita,febriani. 2013. Belajar 16 Tenses. Jakarta: PT. SukaBuku.

Borg, W R \& Gall, M D. 2003. Educational Research: an Introduction (7.ed). New York: Logman Inc.

Budiningsih, 2005. Belajar dan Pembelajaran. Jakarta: Rineka Cipta.

Cameron. 2005. Teaching Languages to Young Learners. UK. Cambridge University Press.

Cornely,Veppy.2010. The Influence Of Using Crossword Puzzle On The Students Writing. Tesis.

Cunningham, Billie M. 2008. Using Action Research to Improve Learning and the Classroom Learning Environment. Journal Issues in Accounting Education.

Dick, Walter. 2005. The Systematic Design of Instruction ( $6^{\text {th }}$ Edition). Boston: Pearson.

Dimyati,Mudjiono, 2013.Belajar dan Pembelajaran. Jakarta: PT. Rineka Cipta.

Dongsong, 2005. Interactive Multimedia Based E-Learning: A Study of Effectiveness. Journal of Distance Education.

Echols, John M dan Shadily, Hassan. 1996. An English-Indonesian

Dictionary. Jakarta:Gramedia.

Facru. 2007. Peningkatan Kualitas Pembelajaran Bahasa Inggris Dengan Media CD Interaktif di SDN 02 Selokaton KEC. Godang Rejo KAB. Karanganyar 2007. Jurnal Teknologi Pendidikan.

Gagne, Robert M (Ed). 1987. Intructional Technology: Foundations. London: LEA Publishers.
Hadi Rizky.2010. Developing a Prototype of Animated Interactive $\mathrm{CD}$ to Teach Reading Comprehension for Seventh Graders. Journal Education.

Hamalik, O. 2006. Media Pendidikan, Certakan ke-7. Bandung: Penerbit PT. Citra Aditya Bakti.

Hamalik, Oemar. 2006. Proses BelajarMengajar. Jakarta: Penerbit PT. BumiAksara.

Hamid, A. 2009. Teori Belajar dan Pembelajaran. Medan.

Handokomudo.2013. Pengembangan Media Pembelajaran Jaringan Komputer Berbasis Macromedia Flash di SMA Negeri 1 Jetis Bantul.Tesis.

Harmer, Jeremy. 2001. The Practice of English Language Teaching. New York: Longman.

Heinich, R \&Heinich, R. 2011. Instructional Media and Technologies for Learning. Englewood Cliffs. N. J: Merrill.

Jamil. Suprahatiningrum. 2013. Guru Profesional: Pedoman Kinerja, Kualifikasi dan Kompetensi Guru. Yogyakarta: Ar-Ruzz Media.

Katz. 2002. Multimedia Dalam Pembelajaran Bahasa Asing. Jurnal Pendidikan.

Khoirun,Henny. 2011. Prototype Media Pembelajaran Matematika Berbasis Multimedia Interaktif Materi Pecahan. Journal Education.

Kevin, Riley. 2006. Service, Learning Evaluation Projects A Step By Step Guide. Journal of Physical Education.

Mahas, Jerry. 2014. Smart Grammar: caracepatmenguasai Grammar. Bandung: PT.Kawah Media.

Mayer, E Richard. 2009. MultiMedia Learning: Prinsip-prinsipdanAplikasi. Yogyakarta: Its Press.

Miarso, Yusufhadi. 2011. Menyemai Benih Teknologi Pendidikan. Jakarta:Prenada Media.

Mubin,Nurul. 2012. Pengembangan Media Pembelajaran IPA Berbasis Multimedia Interaktif. Jurnal Pendidikan.

Reza, Syah. 2011. Pengembangkan Multimedia Interaktif Anak Autis Dengan Metode LOVAAS. Jurnal Teknologi Pendidikan.

Richey,Rita C (Ed). 2000. The Legacy of Robert M. Gagne. New York: ERIC.

Rusman, 2005. Model-model Multimedia Interaktif Berbasis Komputer. Jakarta: UPI 
Sadiman, dkk. 2010. Media Pembelajaran. Jakarta: PT.RajaGrafindoPersada.

Sagala, Syaiful. 2008.Konsep dan Makna Pembelajaran. Bandung: IKAPI

Sarwiko, Dwi. 2010. Pengembangan Media Pembelajaran Berbasis Multimedia Interaktif Menggunakan Macromedia Director MX. Jurnal Teknologi Pendidikan.

Seels, B.B and Richey, R.C.1994. Instructional Technology: the Definition and Domains of the Field (Terjemahan Yusuf HadiMiarso, Dewi S Prawiradilagadan Raphael Rahardjo. IPTPI, Unit Percetakan $\mathrm{UNJ}$ )

Smaldino. 2011. Instructional Technology and Media For Learning. Jakarta: Kencana Media Group.

Sofiani, Resita. 2006. Developing a Prototype of E-VOILA: Electronic Vocabulary
Application' for Vocabulary Learning of the Fifth Graders. Journal of Distance Education

Suprihatiningrum, Jamil.2013. Guru Profesional: PedomanKinerja, Kualifikasi, \&Kompetensi Guru.Jogjakarta:Ar-Ruzz Media.

Susilana, Rudi dan Riyana, Cepi. 2008. Media Pembelajaran:

Hakikat, Pengembangan, Pemanfaatan, dan Penilaian. Bandung: Wacana Prima.

Uno, Hamzah B. 2009. Perencanaan Pembelajaran. Jakarta: Bumi Aksara.

Warsita, Bambang. 2008. Teknologi Pembelajaran: Landasan dan Aplikasinya. Jakarta: Rineka Cipta

Young E, Zhao Y. 2007. Report From The 2007 PDK Summit. Bloomington. Journal Focus on Glogal Education 